\title{
A List of North Korean Tephritoid Species (Diptera: Tephritoidea) Deposited in the Hungarian Natural History Museum
}

\author{
Ho-Yeon Han ${ }^{1 *}$ and Yong Jung Kwon ${ }^{2}$ \\ 'Division of Biological Science and Technology, Yonsei University, Wonju, Gangwon 220-710, Korea \\ ${ }^{2}$ School of Applied Biosciences, Kyungpook National University, Daegu 702-701, Korea
}

\begin{abstract}
We here report nine species of Tephritidae and five species of Platystomatidae from North Korea deposited in the Hungarian Natural History Museum (five new Korean records marked with asterisks): Acidiella pachypogon, Campiglossa absinthii*, C. hirayamae, C. loewiana*, Sphaeniscus atilius, Tephritis brachyura*, Tephritis sinensis*, Trupanea amoena, Xanthomyia alpestris*, Rivellia alini, R. apicalis, $R$. asiatica, R. longialata, and $R$. nigroapicalis. Except for $C$. hirayamae, all other species are newly recorded in North Korea. As a result, a total of 22 tephritid and five platystomatid species are recognized for the North Korean tephritoid fauna. In South and North Korea together, a total of 120 nominal species of six tephritoid families are now officially recognized (1 Lonchaeidae, 1 Pallopteridae, 1 Ctenostylidae, 14 Platystomatidae, 14 Pyrgotidae, and 89 species of Tephritidae).
\end{abstract}

Keywords: Tephritidae, Platystomatidae, taxonomy, North Korea, HNHM

\section{INTRODUCTION}

Tephritoidea is a large superfamily of nine acalyptrate fly families including over 7,300 described species worldwide (Korneyev, 1999; Han and Ro, 2005): the Lonchaeidae, Piophilidae, Pallopteridae, Richardiidae, Ulidiidae, Platystomatidae, Pyrgotidae, Ctenostylidae and Tephritidae (including Tachiniscidae). The enigmatic family Ctenostylidae is here included in the superfamily based on our molecular study using mitochondrial DNA analysis (Han and Ro, in prep.).

Unlike South Korea where the tephritoid fauna is better known, only 14 species of the family Tephritidae (Dirlbek and Dirlbekova, 1972, 1974, 1975; Dirlbek, 1992) and no other tephritoid families are previously known from North Korea: Acanthonevra amurensis (Portschinsky, 1892); Anastrephoides matsumurai Shiraki, 1933 (as A. annulifera Hering, 1940); Anomoia expressa Dirlbek, 1992; Campiglossa defasiata (Hering, 1936) (as Paroxyna frolica Dirlbek and Dirlbekova, 1974); C. deserta (Hering, 1939) (as P. sada Dirlbek and Dirlbekova, 1974); C. hirayamae (Matsumura, 1916) (as C. matsumotoi Shiraki, 1968); Cornutrypeta spinifrons (Schroeder, 1913) (as Vidalia diddiba Dirlbek and Dirlbekova, 1975); Cornutrypeta superciliata (Frey, 1935) (as V. jibadaua Dirlbek and Dirlbekova, 1975); Paragastrozona japonica Miyake, 1919; Paratephritis takeuchii Ito,

*To whom correspondence should be addressed

Tel: 82-33-760-2254, Fax: 82-33-760-2183

E-mail: hyhan@yonsei.ac.kr
1949; Pseudhemilea longistigma Shiraki, 1933; Tephritis carcassa Dirlbek and Dirlbekova, 1974; Tephritis femoralis Chen, 1938; and T. ismene Hering, 1953 (as T. separata Rondani, 1871). Dirlbek (1992) also mentioned the following three species as North Korean tephritids but was not sure about their identifications: Campiglossa parvula (Loew, 1862), Oxyna lutulenta Loew, 1869, and Urophora mandschurica Hering, 1940. These records need to be verified based on actual examination of the voucher materials.

We were able to obtain a number of North Korean tephritoid specimens when YJK visited the Hungarian Natural History Museum (HNHM) in April, 1994. These specimens had been resulted from the expeditions made by Hungarian Entomologists between 1970 and 1977 (Park and Lee, 1991). Based on the HNHM collection we here report nine species of Tephritidae and five species of Platystomatidae, of which five tephritids are new to Korean Peninsula. Except for Campiglossa hirayamae, all other species are newly recorded in North Korea. Therefore, a total of 22 tephritid and five platystomatid species are now recognized for the North Korean tephritoid fauna.

In South and North Korea together, a total of 120 nominal species of six tephritoid families are now officially recognized: 1 Lonchaeidae (MacGowan, 2007); 1 Pallopteridae (Merz and Sueyoshi, 2002), 1 Ctenostylidae (Han, 2006), 14 Platystomatidae (Hara, 1987; Byun and Han, 2004), 14 Pyrgotidae (Kim and Han, 2009), and 89 species of Tephritidae (Han and Kwon, 2000; present study). 


\section{MATERIALS AND METHODS}

We follow Norrbom et al. (1998) and Wang (1998) for the current classification and distribution. We provide color photographs and diagnostic characters to aid identification of the included species. Consecutive digital images in different focal planes (usually 10 or more shots per a specimen) were taken with a digital camera (Panasonic DMC FZ50 mounted with Raynox DCR-250 macro filter) and the images were Z-stacked using Helicon Focus software (Helicon Soft, Ltd). Because most available North Korean specimens are in poor condition, we selected the photographs of South Korean specimens in better shape except for Campiglossa loewiana, Tephritis brachyura, and Xanthomyia alpestris.

The North Korean specimens used in this study are deposited in the Hungarian Natural History Museum, Budapest, Hungary (HNHM). All other specimens used for comparisons are deposited in the Division of Biological Science and Technology, Yonsei University, Wonju, Korea (YSUW). The abbreviations of the other institutions mentioned in the text are as follows: The Natural History Museum, Department of Entomology, London, England (BMNH); Deutsches Entomologisches Institut, Deutschen Akademie der Landwirtswissenschaften zu Berlin, Germany (DEI); Entomological Institute, Faculty of Agriculture, Hokkaido University, Sapporo, Japan (HUS); Institute of Zoology, Academia Sinica, Insect Collection, Beijing, China (IZAS); Systematic Entomology Laboratory, School of Applied Bioscience, Kyungpook National University, Taegu, Korea (KPNU); Museo Zoologico "La Specola", Firenze, Italy (MZLS); Naturhistorisches Museum Wien, Vienna, Austria (NMW); Naturhistoriska Riksmuseet, Sektionen fur entomologi, Stockholm, Sweden (NRS); National Taiwan University, Department of Plant Pathology and Entomology, Taipei, Taiwan (NTU); Polish Academy of Science, Museum of the Institute of Zoology, Warsaw, Poland (PAN); Entomological Laboratory, University of Osaka Prefecture, Osaka, Japan (UOPJ); University of Copenhagen, Zoological Museums, Department of Entomology, Copenhagen, Denmark (UZMC); and Museum fur Naturkunde der Humboldt Universitat zu Berlin, Bereich Zoologisches Museum, Berlin, Germany (ZMHU).

\section{LIST OF SPECIES IN HNHM}

Family Tephritidae Newman, 1834

$1 * 1$. Acidiella pachypogon (Ito) (Fig. 1A)

Pogonangelus pachypogon Ito 1984: 110. TL: Japan, Honshu, Sinano, Kamikoti. Holotype ơ (UOPJ).
Pogonangelus assimilis Kwon 1985: 67. TL: Korea, Gyeonggi-do, Gwangneung. Holotype 우 (KPNU). See Remarks for the synonymic history.

Pogonangelus pachypogon Ito 1956: 24. Nomen nudum. Published after 1930 without a description.

Recognition. This species can be readily distinguished from any other Korean tephritids by the following combination of characteristics (Fig. 1A): 1) body almost entirely yellow brown except for dark brown wing pattern and oviscape; 2) with 2 pairs of black orbital and 3 pairs of black frontal setae; and 3 ) with 3 or more strong dark brown genal setae.

North Korean material examined(HNHM). Gaesong-si: 1 우, Bagyeon waterfall, Hung. Zool. Exp. 1. in Korea. No. 100, 7.VI.1970 (S. Mahunka \& H. Steinmann).

Other material compared(YSUW). SOUTH KOREA: 1 우 (Fig. 1B), Gangwon-do, Wonju-si, Panbu-myeon, Mt. Baegunsan, 21.VI.2005 (H.-Y. Han et al.).

Distribution. Korea, Japan

Remarks. Synonymy of Pogonangelus assimilis with Acidiella pachypogon was first suggested by Han (1992, Ph.D. dissertation; not an available publication for the purposes of zoological nomenclature) and followed by Wang (1998) and later authors.

$2 * 2$. Campiglossa absinthii (Fabricius), New Korean Record (Fig. 1B)

Tephritis absinthii Fabricius 1805: 322. TL: Daniae [Denmark] e Siellandia [Sjaelland?]. Lectotype శூ (UZMC). Lectotype designated by White 1986: 151.

Musca cinereus Harris 1780: 75. TL: England. Type depository unknown.

Tephritis alethe Newman 1833: 506. TL: England, BirchWood and Southgate. depository unknown.

Oxyna parvula Loew 1862: 89. TL: n. Germany. Lectotype

우 (ZMHU). Lectotype designated by White 1986: 151.

Oxyna dracunculi Rondani 1870: 124. TL: Gallicum [France]. Holotype ơ (MZLS).

Recognition. This is the smallest known Campiglossa species in Korea. It can be readily distinguished from other Korean Campiglossa species by the following combination of characteristics (Fig. 1B): 1) both posterior notopleural and upper anepisternal setae white; 2) legs entirely yellow brown with dark setae and setulae; 3) pterostigma with single hyaline spot; and 4) anal lobe and basal 2/3 of cell dm almost entirely hyaline.

North Korean material examined(HNHM). Yanggang-do: 2 Ђ, Mt. Baekdusan, Samjiyeon Hotel, lake shore, No. 381,

${ }^{1 *}$ 시골과실파리, ${ }^{2} *$ 애 흰털좀과실파리 (신칭) 


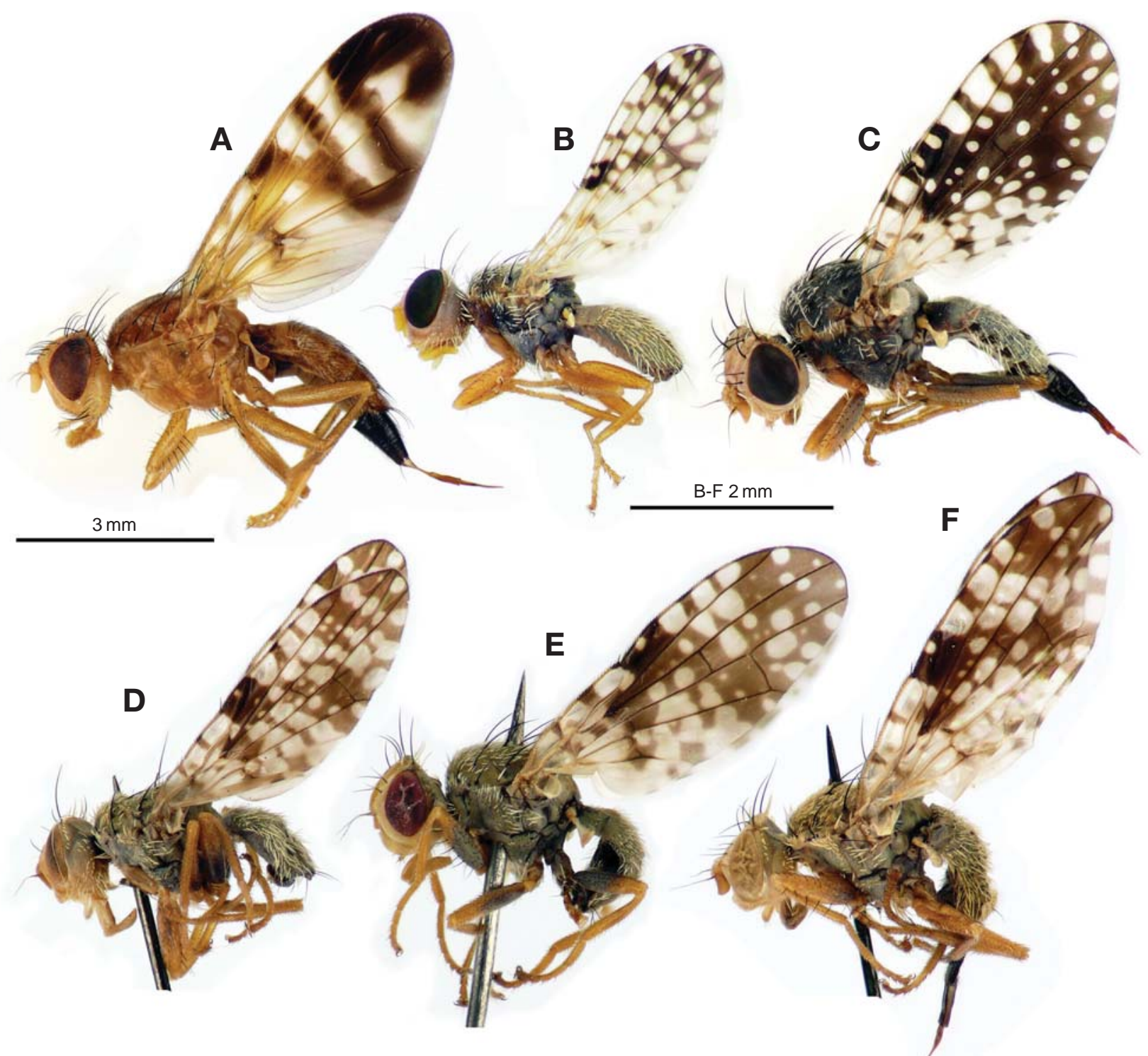

Fig. 1. A, Acidiella pachypogon (Ito), female; B, Campiglossa absinthii (Fabricius), male; C, Campiglossa hirayamae (Matsumura), female; D, Campiglossa loewiana (Hendel), North Korean male; E, ditto, European male; F, ditto, North Korean female.

netting in grasses, 18.VII.1977 (Dely \& Draskovits); $3 \sigma^{7}$ 1우, same except 20.VII.1977; 1 우, same except Samjiyeon Hotel, lake shore; $10^{7}$, Mt. Baekdusan, 20.VII.1977 (Draskovits).

Other material compared (YSUW). SOUTH KOREA: $10^{7}$ (Fig. 1B), Gangwon-do, Jeongseon-gun, Mt. Mindungsan, 4.VIII.2005, YSUW090915027 (H.-Y. Han et al.).

Distribution. n. and cent. Europe to Siberia; Israel, Iran, India, Koera, China, Taiwan.

Remarks. Even though this species is newly recorded in Korean peninsula, it is a relatively common species in South Korea. Adult flies can be easily collected by sweeping in the fields where Artemisia plants are prevalent.

\section{1*3. Campiglossa hirayamae (Matsumura) (Fig. 1C)}

Tephritis hirayamae Matsumura 1916: 423. TL: Japan, Honshu, Tokyo. T 우 (HUS).

Campiglossa conformis Zia 1937: 197. TL: China, Jiangsu, Zi-Ka-Wei. Holotype 우 (IZAS).

Campiglossa hensanica Zia 1939: 9. TL: China, Hunan, Nanyoh [Nanyoe]. Holotype 우 (IZAS).

Recognition. This species is readily distinguished by the following combination of characteristics (Fig. 1C): 1) heavily

\footnotetext{
$1 *$ 국화과실파리
} 
grey pollinose scutum and scutellum with round dark brown markings at the bases of acrostichal, dorsocentral, and basal scutellar setae; 2) femora largely dark brown; 3) both posterior notopleural and upper anepisternal setae black; 4) pterostigma with 2 hyaline spots; and 5) anterior half of anal lobe with distinct dark brown markings.

North Korean material examined (HNHM). Gangwon-do: 1 이 1 우, Mt. Geumgangsan, 3-4 km S. Hotel Geumgang, No. 363, netting in grasses, 12.VII.1977 (Dely \& Draskovits). Pyeongannam-do: 1 우, Mt. Changlyeongsan, $50 \mathrm{~km} \mathrm{~N}$ of Pyeongyang, No. 169, 13.VIII.1971 (Horvatovich \& L. Papp); 1 우, Mt. Lyongaksan, $25 \mathrm{~km}$ W of Pyeongyang, No. 226, 31.VIII.1971 (Horvatovich \& L. Papp). Yanggang-do: 1 우, Mt. Baekdusan, vicinity of Lake Cheonji, 2000-2500 m, No. 372, netting in grasses, 18.VII.1977 (Dely \& Draskovits); 1 ð , Mt. Baekdusan, 18.VII.1977 (A. Draskovits); $1 \sigma^{\nearrow}$, same except 19.VII.1977. “Tesson”, 1 ð, 35 km SW of Pyeongyang, water basin, No. 343, netting in grasses, Dely \& Draskovits, 4.VII.1977 (Dely \& Draskovits). "Sa Gam", $1 \Im^{7}, 30-40 \mathrm{~km} \mathrm{~N}$ of Pyeongyang, water basin, wood, 5.VII. 1977 (Dely \& Draskovits).

Other material compared(YSUW). SOUTH KOREA: 1 우 (Fig. 1C), Gyeongsangbuk-do, Bonghwa-gun, Myeonghomyeon, Mt. Cheongnyangsan, 30.VI.2007 (H.-Y. Han et al.). Distribution. e. Russia, Mongolia, China, Korea, Japan, Taiwan.

\section{1*4. Campiglossa loewiana (Hendel), New Korean Record (Fig. 1D-F)}

Paroxyna loewiana Hendel 1927: 154. TL: Austria, Schneeburg, Alpl. Lectotype 우 (NMW). Suspension of I.C.Z.N. rules required to validate usage. Lectotype designated by White (1986: 152).

Tephritis theora Newman 1833: 506. TL: Scotland and England. Syntype depository unknown. Has priority over loewiana, but synonymy uncertain.

Recognition. This species can be distinguished from other Korean Campiglossa species by the combination of the following characteristics (Fig. 1D-F): 1) posterior notopleural seta white but upper anepisternal seta black; 2) femora largely yellow brown but with some dark brown areas basally; and 3) pterostigma with single hyaline spot. This species superficially resembles $C$. defasciata $(=C$. frolica $)$, but can be distinguished by the above character 2 .

North Korean material examined(HNHM). Yanggang-do: 6 지 4 우, Mt. Baekdusan, 18.VII.1977 (A. Draskovits); 2 주, same except 19.VII.1977.

Other material compared(YSUW). SWITZERLAND: 1 우
(Fig. 2E), GR 1490 m, Valbella/Casoja, 26.VII.1999 (B. Merz).

Distribution. British Is. and Scandinavia S to France, Albania and Ukraine, E to Mongolia, China, e. Russia and Korea. Remarks. The North Korean specimens of this species are almost identical to the European specimens collected near the type locality (Fig. 1D, F vs. E) except that the Korean specimens have less extensive dark markings on femora. Nevertheless we believe it is within the range of normal infra-specific variation in such a widely distributed species. No South Korean specimens of this species have been discovered yet.

\section{2*5. Sphaeniscus atilius (Walker) (Fig. 2A)}

Trypeta atilia Walker 1849: 1021. TL: China. Jiangxi, Foochow [Fuzhou]. Lectotype o (BMNH). Lectotype designation by inference of holotype by Hardy 1959: 210.

Trypeta melaleuca Walker 1864: 238. TL: Indonesia, Maluku, N. Ceram [Seram Laut]. Lectotype $\sigma^{\top}$ (BMNH). Lectotype designation by inference of holotype by Hardy 1959: 216.

Trypeta sexincisa Thomson 1869: 579. TL: China. Syntype 우 (NRS).

Trypeta formosana Enderlein 1911: 427. TL: Taiwan, Akau. Holotype 우 (PAN).

Recognition. This species can be readily distinguished from any other tephritid species in Korea by the combination of the following characteristics (Fig. 2A): 1) body almost entirely dark brown except some areas on head and legs; 2) with 2 pairs of orbital and 2 pairs of frontal setae; and 3) wing with basal hyaline area clearly defined by almost perpendicular base of discal band from basal $2 / 3$ of cell $\mathrm{c}$.

North Korean specimens examined (HNHM). Pyeongannamdo: 1 기 1 우, Mt. Lyongaksan, $17 \mathrm{~km}$ W of Pyeongyang, No. 160, 11.VIII.1971 (S. Horvatovich \& L. Papp). Nampo-si: 1 ऽ , Waudo-dong, $60 \mathrm{~km}$ SW of Pyeongyang, 400-500 m, No. 339, netting in grasses, 3.VII.1977 (Dely \& Draskovits). Other material compared (YSUW). SOUTH KOREA: 1 우 (Fig. 2A), Gangwon-do, Wonju-si, Heungeop-myeon, Maejiri, Hoechon, 21.VII.1997, YSUW08100125 (H.-W. Byun \& D.-S. Choi).

Distribution. India to e. Russia, Korea and Japan, SE to Australasian and Oceanian Region.

\section{3*6. Tephritis brachyura Loew, New Korean Record} (Fig. 2B)

Tephritis brachyura Loew 1869: 22. TL: Russia. Sarepta region. Syntype 아우 (ZMHU).

\footnotetext{
$1 *$ 큰흰털좀과실파리 (신칭), ${ }^{2} *$ 광대과실파리, ${ }^{3 *}$ 백 두과실파리 (신칭)
} 


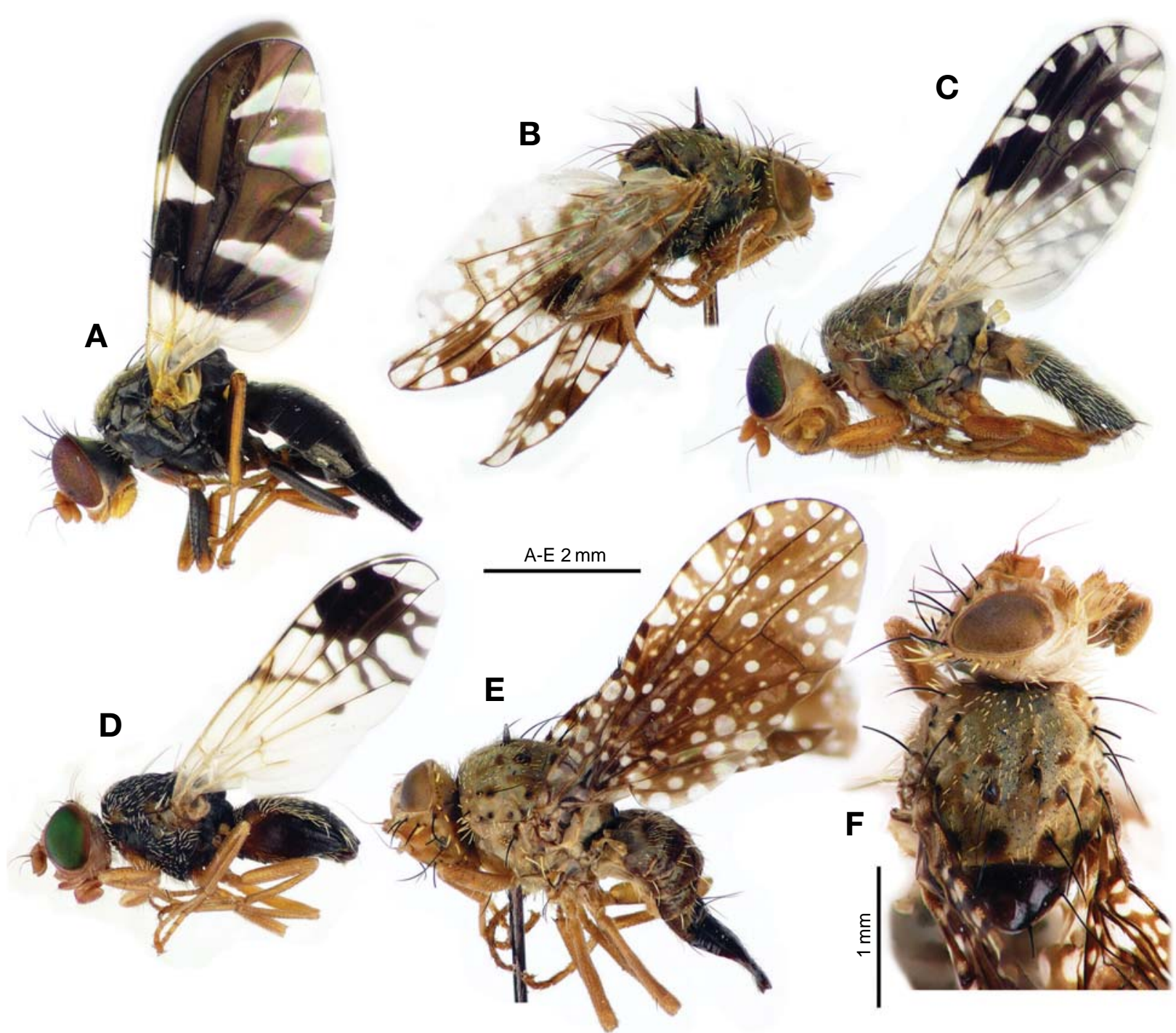

Fig. 2. A, Sphaeniscus atilius (Walker), female; B, Tephritis brachyura Loew, male; C, Tephritis sinensis (Hendel), male; D, Trupanea amoena (Frauenfeld), male; E-F, Xanthomyia alpestris (Pokorny).

Recognition. This species can be distinguished from other Tephritis by the combination of the following characteristics (modified from Wang (1998)): 1) femora almost entirely yellowish brown; 2) oviscape about as long as abdominal tergite 6 ; and 3) wing usually with $4-5$ isolated hyaline spots in cell $\mathrm{m}$.

North Korean specimens examined (HNHM). Yanggang-do: $1 \mathrm{o}^{7}$, Mt. Baekdusan, 20.VII.1977 (Draskovits).

Distribution. Ukraine and s. Russia to Kirghizia, Iran, Korea, China.

Remarks. Only a single male specimen in poor condition was available (Fig. 2B), but its identity appears to be clear based on the diagnostic characters and photographs given by
Wang (1998).

\section{1*7. Tephritis sinensis (Hendel), New Korean Record} (Fig. 2C)

Euaresta sinensis Hendel 1927: 173. TL: China, Sichuan, Mt. Emei (Mt. Omei). Holotype 우 (USNM).

Tephritis pterostigma Chen in Zia and Chen 1938: 156. TL: China, Shanxi, Jiaocheng (Kiao-cheu). Lectotype $\sigma^{7}$ (IZAS). Lectotype designated by Wang 1998: 302.

Tephritis bipartita Hendel 1938: 8. TL: China, Jiangsu. Holotype 우 (NRS).

Tephritis trimacula Ito 1952: 12. TL: Japan, Shikoku, Trugiyama. Holotype 우 (UOPJ).

1*산국과실파리 (신칭) 
Recognition. This species can be distinguished by any other Korean Tephritis by having the pterostigma with hyaline triangular basal spot (Fig. 2C).

North Korean specimens examined (HNHM). Pyeongannamdo: 1 우, Mt. Changlyeongsan, $50 \mathrm{~km} \mathrm{~N}$ of Pyeongyang, No. 169, 13.VIII.1971 (Horvatovich \& L. Papp).

Other material compared(YSUW). SOUTH KOREA: $1{ }^{7}$ (Fig. 2C), Gangwon-do, Wonju-si, Heungeop-myeon, Maejiri, Yonsei Univ. Campus, col. 22.X.2001, em 16.V.2002, ex Chrysanthemum zawadskii, flower, YSUW090915049(H.Y. Han et al.).

Distribution. Korea, China, Japan.

Remarks. Even though this species is newly recorded for the Korean fauna, it is actually a common species that can be easily reared from the flower heads of Chrysanthemum boreale Makino in South Korea (Han, personal data).

\section{$1 * 8$. Trupanea amoena (Frauenfeld) (Fig. 2D)}

Trypeta amoena Frauenfeld 1857: 542. TL: Croatia, Dalmatien [Dalmatia], Zara [Zadar]; \& unstated locality [probably Germany or Austria. Vienna area]. Syntype 주 우 (NMW). Suspension of I.C.Z.N. rules required to validate usage.

Trypanea amoena var. kotoshoensis Shiraki 1933: 452. TL: Taiwan. Kotosho. Syntype o 우 (NTU).

Urellia parisiensis Robineau-Desvoidy 1830: 775. TL: France. Paris. Syntype (MNHNP; destroyed). Has priority over amoena, but synonymy uncertain (Hendel 1927: 198).

Recognition. This species can be readily distinguished from the other known congeners in Korea and surrounding areas by the following wing characteristics (Fig. 2D): 1) two brown bands to margin through cell $\mathrm{m}$; 2) with narrow brown band extends from pterostigma to subapical area of cell br; and 3) apices of cells $r_{2+3}$ and $r_{4+5}$ from narrowly triangular hyaline area.

North Korean specimens examined(HNHM). "De Sang-san", $1 \delta^{7}, 25$. VII.1977 (A. Draskovits).

Distribution. widesp. s. Palearctic Region, Ethiopia, India, Sri Lanka, Australia.

Other material compared(YSUW). SOUTH KOREA: $1{ }^{7}$ (Fig. 2D), Jeju-do, Jocheon-eup, Namjoro resting area, 19. X.2005, YSUW090915105 (H.-Y. Han et al.).

Remarks. This species is relatively rarely collected in South Korea.

\section{2*9. Xanthomyia alpestris (Pokorny), New Korean Record (Fig. 2E, F)}

Carphotricha alpestris Pokorny 1887: 413. TL: Austria, Tirolian Alps, Stilfserjoch, near Franzenshohe, 2,400 m. Holo- type 우 (HNHM?).

Carphotricha pseudoradiata Becker 1900: 61. TL: Russia, Krasnoyarsk Terr., Jeniseisk [Yeniseisk]. Holotype 우 (NRS).

Campiglossa nigroscutellata Chen 1938: 121. TL: China, Shanxi, Tsai-tchang; e. Mongolia, Ala-yingze. Syntype $\sigma^{7}$ (IZAS).

Recognition. This species can be easily distinguished by the following combination of characteristics (Fig. 2E, F): 1) flagellomere 1 sharply pointed at dorsal apex; 2) upper orbital seta white and lower orbital seta dark brown; 3) 2 pairs of dark brown frontal setae; and 4) scutellum convex, shiny dark brown.

North Korean specimens examined(HNHM). Gangwon-do: 2 우, Mt. Geumgangsan, 3-4 km S. Hotel Geumgang, No. 363, netting in grasses, 12.VII.1977 (Dely \& Draskovits). Nampo-si: 1 우, Waudo-dong, $60 \mathrm{~km} \mathrm{SW}$ of Pyeongyang, 400-500 m, No. 339, netting in grasses, 3.VII.1977 (Dely \& Draskovits). Yanggang-do: 1 ד 1 , Mt. Baekdusan, 18.VII. 1977 (Draskovits).

Distribution. Finland, Alps Mts., Russia(Siberia), Kazakstan, Mongolia, Korea \& n. China.

Remarks. This genus is recognized in Korea for the first time. It is the only known Palaearctic species of the genus and the other two species occur in Nearctic region.

Family Platystomatidae Schiner, 1862

3*10. Rivellia alini Enderlein (Fig. 3A)

Rivellia alini Enderlein 1937: 72. TL: China, Mandschurei, Charbin. Syntype 꾸 우 (ZMHU).

Recognition. This species is very similar to $R$. mandschurica but can be distinguished by the following characteristics (Byun et al., 1998) (Fig. 3A): 1) apical parts of cell sc hyaline; 2) preabdominal tergites subshiny and densely rugose; and 3) terminal filaments of aedeagal glans twice as long as basal portion.

North Korean specimens examined(HNHM). Gangwon-do: 5 万 5 우, Mt. Geumgangsan, 10.VII.1977 (Draskovits); 5 万 5 우, same except 11.VII.1977. Yanggang-do: 1 우, Mt. Baekdusan, 20.VII.1977 (Draskovits).

Other material compared(YSUW). SOUTH KOREA: 1 우 (Fig. 3A), Gangwon-do, Jeongseon-gun, Mt. Mindungsan, 14.VI.2004 (H.-Y. Han et al.).

Distribution. China (Manchuria), Russian Far East, Korea, Japan.

\footnotetext{
$1 *$ 상추과실파리 (개칭), ${ }^{2} *$ 광택방패 과실파리 (신칭), ${ }^{3 *}$ 알린 콩알락파리
} 


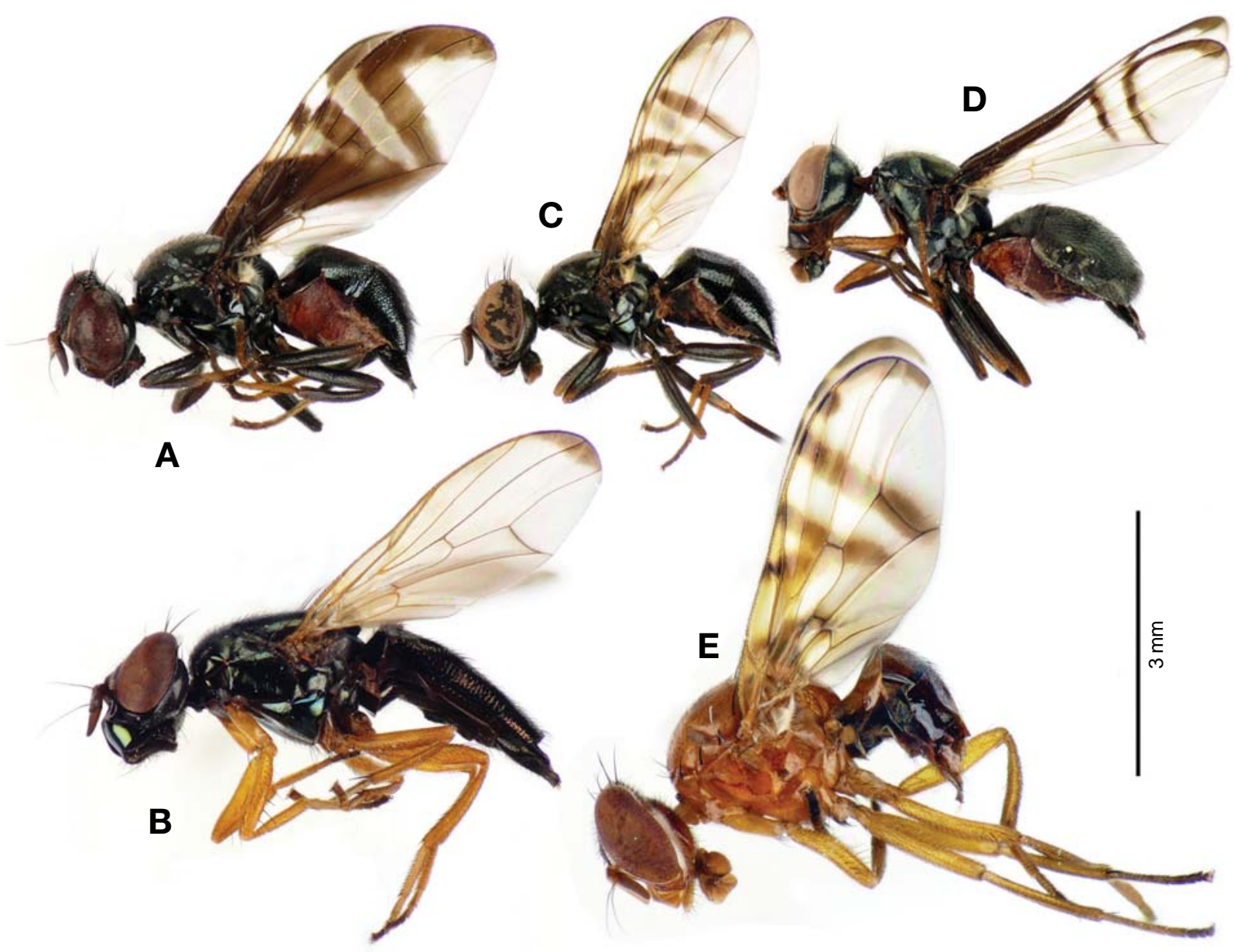

Fig. 3. A, Rivellia alini Enderlein, female; B, Rivellia apicalis Hendel, female; C, Rivellia asiatica Hennig, female; D, Rivellia longialata Byun and Suh, female; E, Rivellia nigroapicalis Byun and Suh, female.

\section{$1 *$ 11. Rivellia apicalis Hendel (Fig. 3B)}

Rivellia apicalis Hendel 1934: 10. TL: China, N. E. Sechuan.

Holotype ơ (NRS).

Recognition. This species can be readily distinguished by any other Korean Rivellia by its almost hyaline wing with a dark anterior apical spot (Fig. 3B).

North Korean specimens examined (HNHM). "De Sang-san", 1우, 25.VII.1977 (A. Draskovits).

Other material compared (YSUW). SOUTH KOREA: 1 우 (Fig. 3B), Jeju-do, Jeju-si, grassland in and around Jeolmul recreational foreset, 26.VIII.2003 (H.-Y. Han et al.).

Distribution. China, Korea, Japan

2*12. Rivellia asiatica Hennig (Fig. 3C)

Rivellia asiatica Hennig 1945: 8. TL: China, Mandschuria. Syntype o 우 (DEI).
Recognition. This species can be distinguished from any other Korean Rivellia by the short subbasal wing band fused with basal band on cells bc and c (Byun and Han, 2004) (Fig. 3C). North Korean specimens examined (HNHM). Yanggang-do: $10^{7}$, Mt. Baekdusan, 20.VII.1977 (Draskovits).

Other material compared (YSUW). SOUTH KOREA: 1 우 (Fig. 3C), Gangwon-do, Jeongseon-gun, Mt. Mindungsan, 16.VII.2005 (H.-Y. Han et al.).

Distribution. Northeastern China, Siberia, Korea.

Remarks. This is a very rare species in South Korea but probably the most common Rivellia species in Russian Far East near North Korean border (Han, personal observation). Therefore it appears to be more northward distributed species in Korea.

\footnotetext{
3*13. Rivellia longialata Byun and Suh (Fig. 3D)
}

Rivellia longialata Byun and Suh in Byun et al. 1998: 337.

\footnotetext{
$1 *$ 민무늬 콩알락파리, ${ }^{2} *$ 아시아콩알락파리, ${ }^{3 *}$ 긴날개 콩알락파리,
} 
TL: Korea, Gangwon-do, Yonsei University, Maeji-ri, Wonju-si. Holotype శ্ (YSUW).

Recognition. This species is similar to $R$. parilis Frey in body color and wing pattern, but can be distinguished by the following characteristics (Byun et al., 1998) (Fig. 3D): 1) legs entirely dark brown except yellow brown fore femur and midtarsi; 2) wing with basal and apical bands separated; and 3) apex of surstylus extends beyond the apex of cerci in lateral view.

North Korean specimens examined(HNHM). Gangwon-do: 1 万๐, Mt. Geumgangsan, 10.VII.1977 (Draskovits).

Other material compared (YSUW). SOUTH KOREA: 1 paratype 우 (Fig. 3D), Gangwon-do, Wonju-si, Maeji-ri, Yonsei University Campus, 12.VI.1996(H.-W. Byun).

Distribution. Korea.

$1 *$ 14. Rivellia nigroapicalis Byun and Suh (Fig. 3E)

Rivellia nigroapicalis Byun and Suh in Byun et al., 2001: 108. TL: Korea, Gangwon-do, Yonsei University, Maejiri, Wonju-si. HT ठ (YSUW).

Recognition. This species is similar to $R$. cestoventris Byun and Suh in wing pattern, but distinguished by the following characteristics (Byun et al., 2001) (Fig. 3E): 1) scutum with dorsocentral seta; and 2) without distinctive postgenal seta. North Korean material examined (HNHM). Gangwon-do: 1 우, Mt. Geumgangsan, 10.VII.1977 (Draskovits).

Other material compared(YSUW). SOUTH KOREA: 1 우 (Fig. 3E), Gangwon-do, Jeongseon-gun, Mt. Mindungsan, 16.VII.2005 (H.-Y. Han et al.).

Distribution. Korea.

\section{ACKNOWLEDGEMENTS}

We sincerely thank Dr. L. Papp of the Hungarian Natural History Museum for the loan of the North Korean specimens used in this study. This research was supported by the Basic Science Research Program through the National Research Foundation of Korea (NRF) by the Ministry of Education, Science and Technology (2010-0003471). It was also supported in part by the Korean Ministry of Environment (the Eco-technopia 21 Project and the Project on Survey and Excavation of Korean Indigenous Species, NIBR).

\section{REFERENCES}

Becker, T., 1900. Beitrage zur Dipteren-Fauna Sibiriens. Nord-
west-Sibirische Dipteren gesammelt vom Prof. John Sahlberg aus Helsingfors im Jahre 1876 und vom Dr. E. Bergroth aus Tammerfors im Jahre 1877. Acta Soc. Sci. Fenn., Ser. B 26(9): 1-66.

Byun, H.-W. and H.-Y. Han, 2004. Revised key and phylogenetic analysis of Korean Rivellia (Diptera: Platystomatidae), with descriptions of two little known species. Entomol. Res., 34: 83-90.

Byun, H.-W., S.J. Suh, H.-Y. Han and Y.J. Kwon, 1998. A taxonomic study of the Rivellia syngenesiae species group (Diptera: Platystomatidae) in Korea. Korean J. Entomol., 28(4): 327-339.

Byun, H.-W., S.J. Suh, H.-Y. Han and Y.J. Kwon, 2001. A systematic study of Rivellia Robineau-Desvoidy in Korea, with emphasis on the species allied to Rivellia basilaris (Diptera: Platystomatidae). J. Asia-Pac. Entomol., 4(2): 105113.

Chen, S.H., 1938. Subfamily Tephritinae. In Y. Zia and S. H. Chen, Trypetidae of North China. Sinensia, 9(1-2): 57-172.

Dirlbek, J. and O. Dirlbekova, 1972. Neue Bohrfliegenarten (Diptera, Trypetidae) aus der Mongolei. Annot. Zool. Bot., (77): $1-5$.

Dirlbek, J. and O. Dirlbekova, 1974. Drei neue Bohrfliegenarten (Diptera, Trypetidae) aus dem nordkoreanischen Gebiet. Annot. Zool. Bot., (92): 1-5.

Dirlbek, J. and O. Dirlbekova, 1975. Zwei neue Fruchtfliegenarten (Diptera, Trypetidae) der Gattung Vidalia aus Nordkorea. Annot. Zool. Bot., (110): 1-3.

Dirlbek, K., 1992. Neue Anomoia-Art (Diptera, Tephritidae) von Korea. Annot. Zool. Bot., 207: 1-3.

Enderlein, G., 1911. Trypetiden-Studien. Zool. Jahrb. Abt. Syst. Geogr. Biol., Tiere 31: 407-460.

Enderlein, G., 1937. Acalyptrata aus Mandschukuo(Dipt.). Mitt. dt. ent. Ges., 7: 71-75.

Fabricius, J.C., 1805. Systema antliatorum secundum ordines, genera, species, adiectis synonymis, locis, observationibus, descriptionibus. Reichard, Brunsvigae [=Brunswick], p. 322.

Frauenfeld, G.R. von., 1857. Beitrage zur Naturgeschichte der Trypeten nebst Beschreibung einiger neuer Arten. Sitzungsber. Akad. Wiss. Wien, 22: 523-557.

Frey, R., 1935. Neue Diptera brachycera aus Finnland und angrenzenden Landern. III. Not. Entomol., 15: 97-101.

Han, H.-Y., 1992. Classification of the tribe Trypetini (Diptera: Tephritidae: Trypetinae). Dissertation, Pennsylvania State University, University Park. xix + pp. 1-275.

Han, H.-Y., 2006. Redescription of Sinolochmostylia sinica Yang, the first Palearctic member of the little-known family Ctenostylidae (Diptera: Acalyptratae). Zool. Studies, 45: 357-362.

Han, H.-Y. and Y.J. Kwon, 2000. Family Tephritidae. Economic Insects of Korea 3. Insecta Koreana, Suppl. 10: 1-113.

Han, H.-Y. and K.-E. Ro, 2005. Molecular phylogeny of the

\footnotetext{
$1 *$ 끝검정 콩알락파리
} 
superfamily Tephritoidea (Insecta: Diptera): new evidence from the mitochondrial 12S, 16S, and COII genes. Mol. Phylogen. Evol., 39: 416-430.

Hara, H., 1987. A revision of the genus Prosthiochaeta (Diptera, Platystomatidae). Kontyu, 55: 684-695.

Hardy, D.E., 1959. The Walker types of fruit flies (TephritidaeDiptera) in the British Museum collection. Bull. Br. Mus. (Nat. Hist.) Entomol., 8: 159-242.

Harris, M., 1780. An exposition of English insects, with curious observations and remarks, wherein each insect is particularly described; its parts and properties considered; the different sexes distinguished, and the natural history faithfully related. The whole illustrated with copper plates, drawn, engraved, and coloured, by the author. Decad III. Robson Co., London, p. 75 .

Hendel, F.G., 1927. 49. Trypetidae. In: Die Fliegen der palaearktischen Region (ed., E. Lindner), Vol. 5. pp. 1-221, pls. 1-17. Stuttgart.

Hendel, F.G., 1934. Schwedisch-chinesische wissenschaftliche Expedition nach den nordwestlichen Provinzen Chinas, unter Leitung von Dr. Sven Hedin und Prof. Su Ping-chang. Insekten gesammelt vom schwedischen Arzt der Expedition Dr. David Hummel 1927-1930. 13. Diptera. 5. Muscaria holometopa. Ark. Zool., (1933) 25A (21): 1-18.

Hendel, F.G., 1938. Muscaria holometopa (Dipt.) aus China im Naturhistorischen Reichsmuseum zu Stockholm. Ark. Zool., 30A(3): 1-13.

Hennig, W., 1945. 48. Platystomatidae. In Lindner, E., ed., Die Fliegen der palaeaktischen Region, 5(1): 1-56.

Hering, E.M., 1936. Neue sudamerikanische Trypanea-Arten (Dipt. Trypetidae) (13. Beitrag zur Kenntnis der Trypetidae). Rev. Entomol. (Rio J.), 6: 327-332.

Hering, E.M., 1939. Vier neue Bohrfliegen von Fukien (Dipt. Trypet.). (26. Beitrag zur Kenntnis der Trypetidae). Decheniana, 98(B): 143-147.

Hering, E.M., 1940. Alte und neue Bohrfliegen der Erde. 29. Beitrag zur Kenntnis der Trypetiden (Dipt.). Stettin. Entomol. Ztg., 101: 23-34.

Hering, E.M., 1953. Neue Fruchtfliegen von China, Vorderasien, Brasilien und Guatemala. Siruna Seva, 8: 1-16.

Ito, S., 1949. Eine neue Paratephritis-Art aus Japan (Diptera Trypetidae). Trans. Kansai Entomol. Soc., 14(2): 1-3.

Ito, S., 1952. Die Trypetiden der Insel Sikoku, mit den Beschreibungen der in den Inseln Honsyu und Kyusyu weitverbreiteten neuen Arten (Diptera). Trans. Shikoku Entomol. Soc., 3(1): 1-13.

Ito, S., 1956. Beitrag zur Systematik der japanischen Trypeiden [sic] (Diptera). Kinugasa Gakuho, 4: 24-25.

Ito, S., 1984. Die japanischen Bohrfliegen. Maruzen Co., Ltd., Osaka, pp. 110-111.

Kim, S.-K. and H.-Y. Han, 2009. Taxonomic review of the Korean Pyrgotidae (Insecta: Diptera: Tephritoidea). Korean J. Syst. Zool., 25: 65-80.

Korneyev, V.A., 1999. Phylogenetic relationships among the families of the superfamily Tephritoidea. In: Fruit Flies
(Tephritidae): Phylogeny and Evolution of Behavior (Eds., Aluja, M. and A.L. Norrbom). pp. 3-22. CRC Press.

Kwon, Y.J., 1985. Classification of the fruitfly-pests from Korea. Insecta Koreana (Ser. 5), 1985: 49-111.

Loew, H., 1862. Die europaischen Bohrfliegen (Trypetidae). W. Junk, Wien [=Vienna], p. 89.

Loew, H., 1869. Revision der europaischen Trypetina. Z. Gesammten Naturw., 34(7/8): 1-24.

Matsumura, S., 1916. Thousand insects of Japan. Additamenta, Vol. 2 (Diptera). Keisei-sha, Tokyo, p. 423.

McGowan, I., 2007. New species of Lonchaeidae (Diptera: Schizophora) from Asia. Zootaxa, 1631: 1-32.

Merz, B. and M. Sueyosh, 2002. Descriptions of new species of Pallopteridae (Diptera) from Taiwan, Korea and Japan, and notes on some other species from Eastern Asia. Studia Dipterologica, 9: 293-306.

Miyake, T., 1919. Studies on the fruit flies of Japan. Bull. Imp. Cent. Agric. Exp. Stn. Jpn., 2: 85-165.

Newman, E., 1833. Entomological notes. Entomol. Mag., 1: 505-514.

Newman, E., 1834. Attempted division of British insects into natural orders. Entomol. Mag., 2: 379-431.

Norrbom, A.L., L.E. Carroll, F.C. Thompson, I.M. White and A. Freidberg, 1999. Systematic database of names. In: Fruit Fly Expert System and Systematic Information Database (Ed., F.C. Thompson). Diptera Data Dissemination Disk 1 and Myia, pp. 65-251.

Park, K.-T. and B.-H. Lee, 1991. Results of the expeditions to N. Korea by Eastern European countries. In: Collection of Papers on N. Korean Insects (Ed., K.-T. Park). Insecta Koreana, Suppl. 2: 1-13.

Pokorny, E., 1887. (III.) Beitrag zurDipterenfauna Tirols.Verh. Zool. Bot. Ges. Wien, 37: 381-420.

Robineau-Desvoidy, J.B., 1830. Essai sur lesMyodaires.Mem. Pres. Div. Sav. Acad. R. Sci. Inst. Fr. [ser. 2] 2, p. 775.

Rondani, C., 1870. Ortalidinae Italicae collectae, distinctae et in ordinum dispositae. Dipterologiae Italicae prodromus. Pars VII. Fasc. 4 (sect. 1) [concl.]. Bull. Soc. Entomol. Ital., 2: 105-133.

Rondani, C., 1871. Ortalidinae Italicae collectae, distinctae et in ordinem dispositae. Dipterologiae Italicae prodromi. Pars VII Fasc. 4 (sect. 2) [part]. Bull. Soc. Entomol. Ital., 3: 3-24.

Schroeder, G., 1913. Spilographa spinifrons, eine neue Trypetide aus dem Riesengebirge. Stettin. Entomol. Ztg., 74: 177179.

Schiner, I.R., 1862. Vorläufiger Commentar zum dipterologischen Theile der "Fauna Austriaca", mit einer näheren Begründung der in derselben aufgenommenen neuen Dipteren-Gattungen. IV. Wien. Ent. Monatschr., 6: 143-152.

Shiraki, T., 1933. A systematic study of Trypetidae in the Japanese Empire. Mem. Fac. Sci. Agric., Taihoku Imp. Univ. 8 (Entomol. 2), pp. 1-509.

Shiraki, T., 1968. Fruit flies of the Ryukyu Islands (Diptera: Tephritidae). U.S. Natl. Mus. Bull., 263: 1-104.

Thomson, C.G., 1869. Diptera. Species nova descripsit. In K. 
Svenska Vetenskaps-Aka-demien, Kongliga svenska fregatten Eugenies resa omkring jorden under befal af C. A. Virgin, aren 1851-1853. Pt. 2: Zoologie, [Sect.] 1. I nsekter. P. A. Norstedt and Soner, Stockholm, pp. 443-614.

Walker, F., 1849. List of the specimens of dipterous insects in the collection of the British Museum. Part IV. British Museum (Natural History), London, p. 1021.

Walker, F., 1864. Catalogue of the dipterous insects collected in Waigiou, Mysol, and North Ceram, by Mr. A. R. Wallace, with descriptions of new species. J. Proc. Linn. Soc. Lond. Zool., 7: 202-238.

Wang, X.-J., 1998. The fruit flies (Diptera: Tephritidae) of the East Asia Region. Acta Zootax. Sinica (1996) 21 (Suppl.), pp. 1-419.

White, I.M., 1986. A new species of Paroxyna Hendel and notes on the nomenclature of other British Tephritidae (Diptera). Entomol. Mon. Mag., 122: 145-163.

Zia, Y., 1937. Study on the Trypetidae or fruit-flies of China. Sinensia, 8: 103-226.

Zia, Y., 1939. Notes on Trypetidae collected from South China. Sinensia, 10(1-6): 1-19.

Zia, Y. and S.H. Chen, 1938. Trypetidae of North China. Sinensia, 9(1-2): 1-180.

Received October 14, 2010 Accepted November 12, 2010 